\title{
Belphégor
}

\section{Extending the Middlebrow: Italian Fiction in the Early Twentieth Century}

Elke D'hoker and Sarah Bonciarelli

\section{(2) OpenEdition}

\section{Journals}

\section{Electronic version}

URL: http://journals.openedition.org/belphegor/957

DOI: 10.4000/belphegor.957

ISSN: 1499-7185

\section{Publisher}

LPCM

\section{Electronic reference}

Elke D'hoker and Sarah Bonciarelli, « Extending the Middlebrow: Italian Fiction in the Early Twentieth Century », Belphégor [Online], 15-2 | 2017, Online since 23 November 2017, connection on 01 May 2019. URL : http://journals.openedition.org/belphegor/957 ; DOI : 10.4000/belphegor.957

This text was automatically generated on 1 May 2019.

\section{(c) (i) () $\Theta$}

Belphégor est mis à disposition selon les termes de la Licence Creative Commons Attribution - Pas d'Utilisation Commerciale - Pas de Modification 4.0 International. 


\title{
Extending the Middlebrow: Italian Fiction in the Early Twentieth Century
}

\author{
Elke D'hoker and Sarah Bonciarelli
}

1 In 1925 the satirical journal Punch quipped: 'The BBC claim to have discovered a new type, the middlebrow. It consists of people who are hoping that some day they will get used to the stuff they ought to like' (qtd. Grover 35-36). Attacking both the aspirations of the middle classes and the pretensions of the intellectual elite, the phrase has been recorded as one of the earliest uses of the word middlebrow in British culture. Still, the very notion of a 'distinctive in-between space' between high and popular culture had already been around in the early 1920s as part of a growing concern with cultural value, status and literary taste (Ardis 116). At first, middlebrow denoted in a quite neutral way the middle ground between the highbrow and the lowbrow, terms which had been around since the late nineteenth century (MacDonald 7-8). Yet by the late 1930s, the term had become 'nearly always a term of disparagement' (Grover 48). If middlebrow was the last term to appear in what became known as the 'battle of the brows', it was also the first to disappear again as the opposition between high/modernist/intellectual and low/mass/ popular became the accepted critical binary to describe the Great Divide in early to midtwentieth century culture (MacDonald 5). Since the 1990s, however, critics in Britain and the U.S. have started to re-examine and reclaim the third term, middlebrow, as worthy of academic attention. This has led to a steady increase in critical studies of middlebrow readers, authors, texts and culture at large between 1900 and 1950 on both sides of the Atlantic. More recently, the term middlebrow has also spread beyond the AngloAmerican context in which it originated and has been considered as a potentially useful term to describe interwar culture in countries like The Netherlands, France and Spain. ${ }^{1}$ In this paper, we propose to continue this line of research by investigating the presence of the middlebrow in an Italian context. We will discuss the changes in the Italian literary scene in the first part of the twentieth century and the ways in which these changes have so far been conceptualised by Italian critics. We will show how the terms that have been proposed for the new literary phenomena and trends fail to exhaustively cover the varied 
and hybrid Italian fiction output of the time. By way of example, we will zoom in on the work of the once highly successful but now largely neglected novelist, Pitigrilli, to show how he falls in between the categories of popular and avant-garde literature that are routinely applied to early twentieth-century Italy. Before moving to the Italian literary scene, however, we need to trace in more detail the changing and contested meanings of the term middlebrow in Britain and the U.S., both in the interwar period and in contemporary criticism.

\section{The Anglo-American Middlebrow}

2 If the Punch line quoted above is one of the best-known early sneers about the middlebrow, it is not the first usage of the term in writing. In her introduction to The Masculine Middlebrow, Kate MacDonald traces earlier appearances of the term in newspapers in 1923 and 1924 and notes that 'middlebrow was by no means always used negatively, and was not confined to fiction, as is the common perception today' (7). MacDonald quotes in fact from a 1930 editorial of the weekly magazine London Opinion which proudly declares itself 'dedicated to the middlebrow' because 'the middlebrow matters ... It lacks the precious posturing of the one extreme, the crude sensationalism of the other - which is probably why it is just taken for granted' (8). Still, in 1930 Virginia Woolf also wrote, but never published, a damning indictment of the middlebrow as 'the man, or woman, of middlebred intelligence who ambles and saunters now on this side of the hedge, now on that, in pursuit of no single object, neither art itself nor life itself, but both mixed indistinguishably, and rather nastily, with money, fame, power, or prestige' (Woolf 115). While the London Opinion praises the middlebrow for avoiding extremes and covering the middle ground of 'balance, sanity, substance, humour' (qtd. MacDonald 8), Woolf blames the middlebrow middle classes for having no conviction of their own and facilely following commercial fashions. The association of the middlebrow with consumer culture would prove a lasting one: in the 1930s and 1940s the increasingly derogatory label was applied to any writer whose novels 'made the Book-of-the-Month lists in the newspapers and sold in their tens of thousands in book club editions, and packed the shelves of lending libraries' (Humble 2-3).

Both the London Opinion defence of the middlebrow and Woolf's denunciation of it also indicate that a clear-cut definition of the middlebrow was lacking. While middlebrow could denote a reader, an author, a cultural artefact, a class of society or even a country, it was perhaps most typically defined by what it was not: the middlebrow was taken to lack the intellectual cachet and seriousness of high culture but also the raciness of the romance, penny-shocker or thriller. For Nicola Humble, 'the middlebrow novel is one that straddles the divide between the trashy romance or thriller on the one hand, and the philosophically or formally challenging novel on the other: offering narrative excitement without guilt, and intellectual stimulation without undue effort' (11-12). The dividing line between highbrow and middlebrow was hotly contested during the 'battle of the brows'. The self-proclaimed highbrows were anxious to distinguish their work from the much more popular middlebrow in terms of aesthetic quality, while middlebrow authors frequently satirized highbrow intellectuals for their precious posturing and wilful obscurity. Because of the greater cultural capital of modernist authors and their long legacy through the academic discipline of literary criticism, the highbrow disdain for middlebrow mediocrity has profoundly shaped the critical understanding of twentieth- 
century literature. In the second half of the twentieth century, middlebrow authors and texts were marginalized and forgotten to such an extent that the term itself - unlike that of lowbrow or popular literature - disappeared from the critical agenda.

This started to change only since the 1990s, under the influence of both feminist criticism and the critique and expansion of modernist studies. In their studies of women's fiction in inter-war Britain, Nicola Beauman and Alison Light successfully recovered the work of several forgotten women writers and highlighted the hidden gender dimension of the battle of the brows: fiction by and for women was almost invariably rejected as middlebrow by the intellectual and academic elite. Their work was continued and expanded by Nicola Humble in her influential 2001 study The Feminine Middlebrow Novel, 1920 s to 1950s. At the same time, a critique of the insularity of modernist studies also lead to the rediscovery of some middlebrow writers under such labels as 'modernisms' or 'intermodernisms' (Hapgood and Paxton; Ardis; Bluemel), while within American cultural studies, critics like Joan Rubin and Janice Radway mapped the emergence of middlebrow culture in the U.S.. Although some of these critics were wary about using the term middlebrow with its overall negative connotations and its association with Victorian phrenology debates ${ }^{2}$, the concept has now returned to the critical agenda and the texts, authors, readership and cultural context of the middlebrow are being explored from a variety of interesting perspectives (see MacDonald; Brown and Grover; Sullivan and Blanch).

5 Yet with the renewed currency of the term also returns the challenge of defining it. Even apart from the difficulties of rehabilitating a concept that has had such bad press in the past, critics are also faced with the many different ways in which the term is - and has been - used. What exactly do middlebrow authors, middlebrow readers, middlebrow music, middlebrow books and middlebrow taste have in common? And even within the field of middlebrow literature, which is our main concern here, the pressing question is: what makes a text middlebrow? - 'Is it a question of theme, style, popularity or readership?' (Brown 6). Surveying recent scholarship, three distinct approaches can be discerned depending on the emphasis that is put on the reader, the text, or the author in the definition of middlebrow.

6 As the foregoing brief historical survey has shown, the term middlebrow emerged as part of the contentious reception of literary texts and other cultural products in the early twentieth century. For Erica Brown in Comedy and the Feminine Middlebrow Novel, middlebrow should therefore only be seen as a label construed through complex cultural processes of reception: 'The view I take in this study is that there is no fixed, essential characteristic of a text that is middlebrow. Instead middlebrow is a pejorative label that is applied to express specific prejudices ... prejudices towards feminine and domestic themes, of narrative modes that are regarded as outdated, and to a mass, female, middleclass readership' (6-7). Similarly, Nicola Humble is keen to stress that the middlebrow refers merely to the shift in appreciation of realist fiction after the advent of modernism: 'It is not (as many critics would have us assume) that novelists, and particularly female novelists, suddenly started writing meretricious, class-obsessed fripperies in the years after the First World War, but rather that the status of the realist novel was dramatically altered by the coming to public consciousness of the modernist and associated avantgarde movements' (11). A key factor in the reception of texts as middlebrow was, of course, their popularity and bestseller-status. Through bestseller lists, book clubs and lending libraries, middlebrow novels reached a huge proportion of the expanded 
readership in the interwar years. In addition, class issues played an important part in the cultural construction of the middlebrow, particularly in Britain. As Humble puts it, 'a novel was therefore middlebrow not because of any intrinsic content, but because it was widely read by the middle-class public - and particularly by the lower middle classes' (13). In a later article, she also elaborates on the widespread notion that middlebrow literature was, if not exactly escapist reading like lowbrow romances and westerns, certainly perceived as leisure reading. Unlike the intellectually challenging highbrow texts which seemed to require serious study, these were books that could be enjoyed for relaxation. Hence, she concludes somewhat provocatively, 'middlebrow and highbrow books are distinguishable, fundamentally, not by any stable intrinsic differences, but by how they are read' ('Sitting' 46).

However, defining middlebrow novels only in terms of their reception - how they are read by readers and labelled by critics - is not without its difficulties. On the one hand, it rather inconveniently limits the use of the term to texts and authors that were explicitly branded as middlebrow at any stage of their career. On the other hand, even if we grant that class snobbery, gender bias and academic posturing did play a role in the reception of texts as middlebrow, the question remains whether there are not also textual thematic, stylistic, narrative - features of a text that determine its reception as middlebrow. This tension between a text- or reader-oriented approach to middlebrow also marks out the work of Brown and Humble referred to earlier. Even while defining middlebrow as only a pejorative label, Brown proceeds to trace a shared use of comedy in the middlebrow texts she discusses and Humble too admits in an interview to 'wavering between the position that the middlebrow is just about reception, or even ... about reading posture, about how a book is read, and the idea that there is something more generic, more substantial to it, that there are certain characteristics of the middlebrow' (D'hoker and Humble 261).

8 Several critics have therefore also sought to formulate text-intrinsic characteristics of middlebrow literature. As we have seen, Humble herself notes that the middlebrow novel 'straddles the divide between the trashy romance or thriller on the one hand, and the philosophically or formally challenging novel on the other: offering narrative excitement without guilt, and intellectual stimulation without undue effort' (Feminine Middlebrow 11-12). And in a study on J.B. Priestly, Ina Habermann concludes

middlebrow fiction should meet certain 'moderate' aesthetic and intellectual expectations. It should, therefore, in addition to being carefully written, relate to literary traditions, history, philosophy and science ... The function of such narratives is neither 'mere escapism' ... and light entertainment, nor intellectual challenge through aesthetic innovation, but an imaginative projection of lived experience conducive to a negotiation of identity and emotional 'entertainment' in the sense of providing sustenance. (35)

As these definitions suggest, the middlebrow is often described in terms of a mixture of highbrow and lowbrow elements that avoids the excesses of both. Middlebrow novels offer a combination of entertainment and intellectual sustenance, of emotional identification and social relevance, of engaging plot and a sense of style. As Humble puts it, 'It is an essentially parasitical form, dependent on the existence of both a high and a low brow for its identity, reworking their structures and aping their insights, while at the same time fastidiously holding its skirts away from lowbrow contamination, and gleefully mocking highbrow intellectual pretensions' (Feminine Middlebrow 12). The parasitical - or, to use a more positive term, hybrid - nature of the middlebrow is also recognized by the 
editors of the 2011 special issue on middlebrow of Modernist Cultures. They call the hybridity of the middlebrow, 'a governing principle' of the whole issue and note 'the hybridity of the middlebrow is not mimicry of the highbrow, but a sophisticated integration of a range of cultural practices in order to provide an entertaining and intellectual understanding of modernity' (4-5).

10 This emphasis on the function of middlebrow as negotiating highbrow culture and making it accessible to a larger audience brings us to the third approach in defining the term - through reference to the intentions of authors and other agents in the literary field. This is the approach that dominates American scholarship on middlebrow literature and culture. Lacking the class anxiety of British writers and critics, mid-twentiethcentury American critics seem to have used the term in a less pejorative fashion. In 1933 Margaret Widdemer recognised as middlebrow 'the majority reader', between the 'tabloid addict class' and the 'tiny group of intellectuals' (qtd. Rubin xii). Moreover, American critics were keen to stress the mediating and edifying role of middlebrow literature as a means of improving the ever-expanding readership through 'self-realisation' (Grover 38-40). Contemporary American critics also emphasise this pedagogical dimension of the middlebrow. John Guillory defines 'middlebrow culture [as] the ambivalent mediation of high culture within the field of the mass cultural' (87) and in What America Read, Gordon Hutner characterises middlebrow novels as novels that 'mean to please and instruct middle-class America in all its diversity of social marking, economic position, political standing' (1). This characterisation of the middlebrow as literature that is geared towards edification and instruction of the general public has also been taken over by researchers in the Netherlands who investigate the role of middlebrow mediators in the literary field in the mid-twentieth century. They characterise middlebrow not in terms of texts or readers, but in terms of 'a variety of practices, aimed at guiding the increasing number of readers through the expanding and commercializing book market' (Van Boven and Sanders).

As both British and American critics note, moreover, middlebrow authors were quick to use a whole set of commercial tools available to them in their attempts at mediating - or commercialising - high culture. In their introduction to Middlebrow Moderns, Lisa Botshon and Meredith Goldsmith argue that middlebrow writers 'successfully made transitions between literature and the burgeoning technologies of magazine publication, book clubs, advertising, radio and film, institutions that deliberately targeted 'middle' audiences for maximum distribution and profits' (4). Their successful exploitation of commercial strategies for marketing books and boosting sales of course in turn further angered the embattled highbrows into equating a high quantity of sales with a deplorable lack of quality. In short, even though the aims of authors, the attitudes of readers and the topics and features of the text itself are undeniably intermeshed in the cultural construction of the middlebrow, all these different critical approaches do highlight different aspects of the middlebrow which will be useful in our tracing of a middlebrow literature in early twentieth-century Italy in what follows.

\section{The Italian literary scene of the 1920s and 1930s}

12 Determining whether the concept of middlebrow might be a useful tool to approach certain aspects of Italy's literary culture of the twenties and thirties requires, first of all, a general description of that socio-cultural context. Many of the cultural changes which 
Italy witnessed in the first decades of the twentieth were similar to other European countries and, indeed, Britain. As David Forgacs notes in his study L'industrializzazione della cultura italiana (1880-2000), literacy levels were extremely low in Italy for much of the nineteenth century. Only at the end of that century did the situation improve as the result of urbanisation and increased education. The expansion of the urban middle class together with growing literacy levels before the first world war and, especially, in the interwar period led to a rapidly expanding readership, which publishers and librarians were eager to respond to. They launched new book series, hired new writers and tried different marketing techniques, such as attractive book covers and advertising, to publicize new titles. If before the first world war, publishers had still encountered difficulties in trying to market and sell their books beyond the urban areas, in the interwar period the logistics of bookselling improved. At the same time, the expanded middle classes across Italy were eager to adopt a more modern lifestyle and to purchase new commodities and new cultural products, including new books.

Forgacs also describes how publishers went through an economic crisis in the first decades of the twentieth century due to the high costs for paper and printing. As a consequence, the big publishers (Garzanti, Mondadori, Treves, Sonzogno, Salani) aimed for bestsellers: they tried to attract new readers by marketing commercial titles, with easily digestible plots such as thrillers, adventure stories, and love stories. In order to have a sufficient offer, these publishers initially produced and marketed translations of foreign titles, but in the course of the interwar period they actively encouraged and equipped Italian authors to write Italian popular novels in order to cater for the tastes of the new reading public. Highly popular series were I Gialli (thriller, detective and noir stories; a detective is still called a giallo in Italian) and I Romanzi della Palma by Mondadori (love stories), I romanzi di Liala (love stories) and I romanzi di Carolina Invernizio by Sonzogno (noir and love stories).

14 All of these socio-cultural changes in Italy in the first decades of the twentieth century increased literacy levels, growth of the middle classes, expansion of the reading public, changes in the production, publication and marketing of books - are similar to the processes which have led to the emergence of so-called middlebrow literature in other European countries. Yet, in Italy such a concept or category did not emerge nor did such a literature seem to exist - or did it? Instead, literary criticism has used various other terms to describe the Italian literary scene of the first half of the twentieth century and the forms of literature which emerged to target the new readership: 'letteratura popolare' (popular literature), 'letteratura d'appendice' (appendix literature), 'letteratura di consumo' (consumer literature), and 'letteratura d'intrattenimento' (entertainment literature). Before proceeding to argue why middlebrow would after all be a useful term to apply to the Italian literary scene of the 1930s, we will therefore give a brief overview of the various terms that have been proposed and the specific emphases these terms imply.

In his essay Il Superuomo diMassa (1976) Umberto Eco discusses what he calls the 'letteratura popolare o d'intrattenimento' of the first half of the twentieth century in Italy. Eco sees the 'letteratura popolare o d'intrattenimento' as the product of a new cultural industry that tries to reach a new readership: the urban middle classes which turn to the novel as a substitute for the religious and aristocratic values that no longer seemed to hold great interest for them. Instead of offering models of heroic or religious virtue, these popular novels stage a cast of realistic characters with which readers could 
be expected to identify. As Eco points out, the popular novel did not seek to invent original situations, but instead used plots which were already well-known from eighteenth- and nineteenth-century Italian novels. Eco also draws attention to the serial origins of the popular novel. Serialising novels in newspapers or journals was an important publication format in nineteenth-century Italy, which had borrowed the practice from France. The fact that these novels - or 'feuilletons' - were published as an 'appendix' to a newspaper explains why the notion 'letteratura d'appendice' is used in literary criticism (Bordoni and Fossati) to describe those twentieth-century popular novels which still carried traces of this serial practice. The form of the serial novel required a certain repetitive, rhythmic technique designed to enable the reader to follow the plot over a considerable duration of time. Even when it became emancipated from the 'feuilleton' tradition and from publication in serial form, the popular novel still retained characteristics of verbosity and repetition in its narrative structure. Still, most of the highly successful novels of the early twentieth century differ from the "letteratura d'appendice' in two important respects: first of all, they no longer make use of a number of narrative devices characteristic of novels published in instalments, such as repetition, 'cliff-hangers', mnemonic techniques and the build-up of suspense towards the end; second, the author functions much more as a marketable 'brand name' than was the case for serial novels. Hence, the terms 'letteratura d'appendice' and 'letteratura popolare' do not really apply to the work of such well-known writers as Pitigrilli, Lucio D'Ambra, Luciano Zuccoli, Guido da Verona, Carolina Invernizio and Liala, who produced popular, best-selling works which nevertheless diverged from the tradition of popular fiction. As we will show, the novels of these writers fall outside the categories of both popular, serialized, genre writing and highbrow literary texts in a way similar to the AngloAmerican middlebrow novels.

Yet another way in which the literary field of the early twentieth century has been described is by means of Carlo Bordoni's term, 'letteratura di consumo'. This term highlights the considerable influence of industrialisation and marketing processes on literary texts from the nineteenth century onwards. As Bordoni argues in his study Il romanzo di consumo, consumer novels aim at fun and entertainment and offer the reader an easy escape from everyday reality. Consumer novels are not difficult, they possess neither originality nor any literary qualities. Usually they are not seen as an object the reader keeps with particular care after reading it. All of this, Bordoni notes, affects the production of the consumer novel: its price, size, cover and paper quality suggest that it is a disposable book, not designed to last (12). In the early twentieth century, the distribution channels for the consumer novel changed: it was no longer only for sale in bookshops, but could be found in stalls or other shops intended to attract readers commuting between home and workplace (12). In 1958, the literary sociologist Robert Escarpit described these distribution circuits, which meet the needs of the worker, the employee and the student, as the 'circuits littéraires populaires' (Escarpit 58).

Again, however, the label consumer novel only seems to apply to the lowbrow section of the large quantities of novels that were published in the early twentieth century. As a disposable book, frequently a specimen of genre fiction - romance, detective or mystery novel - the consumer novel was not meant to be treasured by the reader or to be displayed in a middle-class bookcase. Yet, this does not apply to the beautifully produced novels by Pitigrilli, Lucio D'Ambra, Luciano Zuccoli, Guido da Verona, Carolina Invernizio and Liala, which often had exquisite covers, designed by the leading artists of the time. 
Moreover, in the marketing of these books, the author's name and fame were of central importance and were prominently displayed on the beautiful covers. All of this suggests books designed to be on display in the middle-class home, not the disposable consumer books described by Bordoni.

In the 1970s, Michele Rak suggested the term 'paraliterature' to describe the expansion and marketization of the Italian literary field in the early twentieth century. First used in French literary studies (Arnaud, Lacassin, Tortel), the term covers what is known as genre fiction in English: texts which clearly belong to a specific genre - science fiction, crime fiction, detectives, romance novels, as well as comics or cartoons. Rak identifies the characteristics of paraliterature as follows: i) paraliterature is identified both by those who produce the text and by those who receive it as in opposition to so-called literary texts; ii) paraliterature tends be serialized; iii) the importance of the figure of the author is reduced in paraliterary texts; iv) in paraliterature, the text is not read a second time and tends not to be preserved, v) the paraliterature reader selects the individual text on the basis of the genre it belongs to (12).

This last point is of particular importance: a reader's choice is not dictated by the author and what he or she represents, but by the 'genre' the text belongs to. It is therefore important that the book's cover, the title, the paratext in general as well as the methods of distribution and market placement announce that generic category, thus predicting the plots and generic conventions the reader can expect. As with Bordoni's term 'consumption literature', paraliterature primarily describes the 'lower' substratum of fiction - and the literary field in general - of 1920s and 30s Italy, but fails to adequately cater for the novels of authors such as Pitigrilli, D'Ambra, or Invernizio. Their novels were very successful and attracted a wide readership, yet they do not display the generic patterns described by Rak nor do they belong to the disposable type identified by Bordoni. Moreover, as we have noted already, the name and fame of the author was an important element in the production, marketing and reception of their books, which contradicts the characteristics of popular literature as described by these critics. In short, the position of these authors in between lowbrow, popular fiction and highbrow literary texts has a lot in common with the position and reception of middlebrow authors in Britain and the U.S. in the same period. We would suggest therefore that it would be useful to apply the term middlebrow to the work of these writers so as to characterise their work more accurately and to delineate it against the lowbrow and highbrow literature of the period. Since an exhaustive description of the work of these authors falls beyond the scope of this paper, we will further elaborate these points by means of a case study: the fiction of the Italian author Dino Segre, who wrote under the pen name of Pitigrilli.

\section{Pitigrilli: a middlebrow author}

Dino Segre was born in Turin in 1893 to a Jewish father and an Italian mother. In the 1920s, after finishing law school, he worked as a journalist and editor and wrote novels under the pseudonym of Pitigrilli. His highly readable novels often addressed controversial aspects of contemporary urban life, such as drugs, political intrigues, delinquency, and sex. They quickly became bestsellers in interwar Italy. Pitigrilli's first novel, Mammiferi di lusso (Luxury mammals), was published by Sonzogno in the summer of 1920 and became an immediate bestseller. The first edition counted 20,000 copies and a 
third edition was already published in October of the same year. In 1921, La cintura di castità (The Chastity Belt), a collection of stories, sold 10,000 copies in one month, which established a new sales record. His next novel Cocaina (Cocaine) (1921), which the magazine Mondo described as a 'great ironic, sceptical, and disturbing novel' (Magri 51), caused a great stir and provoked debate in newspapers and magazines. This further boosted sales figures: the novel sold 10,000 copies in 10 days. In 1924, Una vergine a 18 carati (An 18 Carat Virgin) was written in only two months and shattered another sales record. In the same year, Pitigrilli embarked on another important publishing venture: he founded and edited the magazine Le Grandi Firme, which would run until 1939. This magazine aimed to combine popular appeal with graphic experimentation and innovative literature. While some prominent Italian and international writers published in its pages, the magazine also attracted a large readership. In 1929, after a five-year silence due to lawsuits and legal problems, Pitigrilli published L' esperimento di Pott (Pott's Experiment), which is considered his greatest work. As Pitigrilli's final bestseller, the novel concluded the author's golden decade. As this brief overview will have made clear, Pitigrilli's novels display several characteristics of the middlebrow: his novels address contemporary concerns in a readable manner; they may employ certain generic codes but never fall into the fixed conventions of a specific popular genre; his novels were bought and read by a large middle-class readership, which eagerly awaited new work from the celebrated author.

A personal friend of Mussolini, Pitigrilli was closely associated with Fascism in the 1930s. He became an informant for OVRA, the Fascist secret service, and was responsible for the imprisonment of several intellectuals. Yet, the stricter anti-Semitic laws during the war lead to a fall from grace with the Fascist regime and his books stopped being reprinted. After the war, Pitigrilli fled to Argentina. Later, he drifted back to Italy, but his reputation had diminished to the point where almost no one noticed him anymore. He died in 1975 in near total obscurity.

Pitigrilli's neglect in Italian literary criticism of the second half of the twentieth century is partly due to his active involvement with fascism, but it is also the result of the critical categories and values that have been used to describe and evaluate the literary field. As his novels were considered too successful and popular to be included within the historical narrative of highbrow literature, they were automatically relegated to the realm of popular fiction, not worthy of critical attention except in the form of general categories and trends. While the high entertainment value of his novels, their readable and sometimes racy plots did set Pitigrilli apart from the highbrow experimental literature of the period, the stylistic quality of his novels, their intermedial elements and modernist characteristics also bar inclusion in the categories of lowbrow or consumer literature. In short, Pitigrilli's work falls in between the cracks of the existing critical categories. It has thus fallen victim to the all too highly dichotomous nature of Italian literary criticism. To remedy this, we take recourse to the category of the middlebrow as described by AngloAmerican critics. Pitigrilli's work clearly fits this category, with respect to its authorial, textual and readerly characteristics. It thus offers a good test case for the relevance of such a category in the study of Italian literary culture of the twentieth century. What makes the case of Pitigrilli interesting too is the way author and publisher collaborated to produce and market the books in such a way as to attract attention, lure readers and maximize sales figures. Cover, illustrations, frontispiece, typography, and photographs were carefully chosen to make the book as attractive as possible to a specific 
segment of the reading public. Pitigrilli's books all had beautiful covers, made by wellknown artists such as Sergio Tofano and Paolo Garretto. These artists moved freely between the worlds of avant-garde art and advertising. As they were closely associated with the experimental, Futurist avant-garde of the time, their covers lent a special cachet to Pitigrilli's novels. It placed these novels outside the realm of lowbrow, consumer literature, but not quite within the field of highbrow avant-garde literature itself. Yet, Pitigrilli's covers not only borrowed from the highbrow avant-garde, they also drew on advertising techniques and elements from consumer culture to attract the attention of middle-class readers and to compete with other forms of popular culture. In this way, the covers are exemplary for the hybrid nature of the middlebrow as discussed by Nicola Humble and other critics as they blur the boundaries between high and low culture. Pitigrilli's own fame as an author also played a key role in this process, since his own life and experiences were exploited in the creation of an author myth.

The hybridity that characterises the paratext of Pitigrilli's work (covers, branding of the author, marketing) can also be traced in the texts themselves. They too embrace the apparent contradiction between popular success and literary quality, between mass circulation and elitist art. In his novels Pitigrilli typically combines entertaining and realist narrative plots written in an accessible language with experimental stylistic techniques, borrowed from Italian and European modernism. Examples of such techniques are: i) the use of newspaper headlines and advertising slogans, ii) the use of cinematographic narrative techniques, such as short descriptions in fragmented syntax to suggest 'snapshots', and iii) the highly visual dimension of his texts.

As far as the first feature is concerned, in L'Esperimento di Pott (1929), for instance, the advertising world is evoked through references to consumer goods and shopping experiences and through a style that is broken, fragmented and assertive, reminiscent of advertising slogans. In some parts of L' Esperimento di Pott the narrative is composed of several advertising clips put together with newspaper headlines. The narrator's voice is replaced by publicity slogans that acquire meaning and create a textual coherence by being juxtaposed in one single sentence or phrase:

Pott, standing still near a fountain, was pondering about his obscure future, with his eyes focusing on those short-lived sentences that exist and emerge with the purpose of living only for an instance: you can get the best lobsters at Prunier's Poincaré has put the question of trust: and he got it with 308 votes against 262 - the King of England's health is stable - Galeries Lafayette will show the summer clothes collection - today the president of a Tribunal has declared that two of his colleagues are idiots in the middle of a hearing - the face powder that does not ruin your skin is... (38)

In this piece, an advertisement for Prunier lobsters is combined with news headlines regarding Poincaré's political situation, the King of England's health status, an announcement by Galeries Lafayette, and an advertisement for face powder. It is a slice of contemporary urban life, made up of a tight juxtaposition of words, slogans and images. This eruption of reality radically breaks into the protagonist's patterns of thought. The advertising world does not only enter the literary text through slogans and headlines but also through the narrator's frequent use of brand names and logos that would have been familiar to the public during the 1920s and 1930s: 'During theatre intervals, on the advertising screen, between a Pleyel piano ad and that of Boucheron jewellery, the portrait of President Pott was being shown' (38). The outside world breaks into the narrative, influencing its rhythm, style and point of view. Far from being a unique 
characteristic of Pitigrilli's novels, this is a familiar technique of the European avantgarde experimental tradition. In Italy, it was used by many authors of the first decades of the twentieth century, from Aldo Palazzeschi's 1910 La passeggiata to the broken, truncated prose of Achille Campanile's 1932 Battista al Giro d'Italia.

Second, L' Esperimento di Pott is characterised by the use of cinematographic narrative techniques. In the following extract, for instance, the presence of a cinematographic point of view on reality is evident in the reference to a metteur-en-scène at Métro-Goldwin. The reader is invited to focus on the visual aspects of the scene and to imagine the world of the tribunal as part of a film:

One does not need the imagination of a metteur-en-scène of Métro-Goldwin to see Samson $^{3}$ the executioner, in front of the old carts left by the iron railings, or read dreadful lists with the stiff thoroughness of a freight broker, between the victims' piercing goodbyes and the hysterical fits of a crowd that screams in front of gates (13).

Similarly, the description of Paris that follows evokes an edited film sequence that links a series of typical shots of the city:

I am enthusiastic about Paris: Paris at night; Place Pigalle, Place de l'Opera; the Haussman Boulevard corner with Boulevard des Italiens above Café du Brésil looks like a Babel tower lit by a choreographer; the lights at Chaussé [sic] are white with purple nuances, which make taxi lights seem green; it's a fireworks festival, but without the brutishness of the crackers (13).

Third, the style of Pitigrilli's novels is often highly visual: scenes are described in a photographic manner through an effective use of visual details, as in the following instance:

Counsellor Martinet, stroking his big white sideburns, watched him closely with his great blue eyes; his pink face, almost free of wrinkles, with a bright forehead, thick but not stern eyebrows featured on his face, typical of an old fashioned judge (96).

Counsellor Martinet is described with such clarity that it gives the reader the feeling of looking at a photograph. The description is more static than the one we have seen before. Not only in this text, but in all of Pitigrilli's novels there is a great sense of the visual, which could be described through Greimas's term of 'figurativity': a text's ability to convey an image, scene or painting. This photographic or 'figurative' quality of Pitigrilli's novels contributes to their readability and suspense, but also draws on the intermedial characteristics of the experimental literature of the time.

\section{Conclusion}

31 Pitigrilli's use of these stylistic techniques again confirms his position mid-way between the lowbrow and the highbrow. Borrowing elements from both popular culture and the experimental avant-garde, his novels clearly straddle the divide between high and low and can thus be said to belong to the domain of the middlebrow, as it has been described in Anglo-American literary criticism. Of course, in the Anglo-American context, middlebrow is both a historical concept, used by literary actors in the first half of the twentieth century, and a critical category reintroduced to map and study twentiethcentury literature in hindsight. In the Italian context, middlebrow can only be the latter. Yet, if that prevents it from having immediate recognition and wide appeal, it also saves it from the negative connotations that adhered to the term for much of its history in Britain and, to a lesser extent, the U.S.. As this case study of Pitigrilli hopes to have 
shown, as a critical category, the middlebrow can fruitfully be applied to the Italian literary scene of the first half of the twentieth century. It conveniently complements the many critical terms which have been developed for the period, but which primarily apply to the lowbrow and popular end of the literary continuum. As our all too brief discussion of Pitigrilli's novels has shown, his texts certainly display the stylistic, formal and thematic features which are typically associated with the middlebrow. In addition, Pitigrilli's skilful marketing strategies and his negotiation between the popular and the avant-garde literary scene mark him out as a middlebrow writer. In terms of reception, of course, his work cannot have been labelled as middlebrow in mid-twentieth-century Italy as the term did not exist. Still, the high sales figures of his books and his general popularity as a writer do suggest similarities with the reception of middlebrow authors like Warwick Deeping and J.B. Priestley in Britain.

Having established the middlebrow characteristics of Pitgrilli's work, it remains for us to try and explain why his work, and that of other writers like him, was not recognised as occupying this middle territory in Italian literary criticism and was instead relegated to the realms of lowbrow and popular literature. It is useful to refer here to Antonio Gramsci's appraisal of Italian literature and culture in his prison notebooks, and more precisely in the notes published as Letteratura e vita nazionale (1950), which are dedicated to the absence in modern Italy of a popular literature with a wide appeal. Far from limiting this category to lowbrow genre fiction, Gramsci understands popular literature as a broad category which includes the works of major authors aimed at a wider audience. Only such a popular literature can be a truly 'national' literature (letteratura nazionalpopolare), he argues.

For Gramsci, the absence of such a tradition in Italy constitutes one of the major obstacles to producing a literature that truly heralds intellectual and moral renewal. Gramsci's argument is that Italian intellectuals look down upon common people and remain stuck in a patronizing attitude, which produces only artificial, pseudo-popular literature in a top-down process. Italian intellectuals, he argues, are too far from the people, or the 'nation' as he calls it, and too much bound to aristocratic caste traditions. In other words, Italy lacks for him 'organic intellectuals', who put their knowledge and skills at the service of the working class and its struggle. Gramsci's considerations effectively explain how the aristocratic attitude of intellectuals and writers in Italy generated a very strong and rigid division between elite literature and consumer literature, which did not allow for the formation of intermediate forms of literature. Moreover, even when these intermediate forms of literature did emerge, as in the case of Pitigrilli, critics were not able to recognise them, as they were too entrenched in an aristocratic attitude and in a negative view of certain literary categories such as the penny dreadful and popular literature. In the Anglo-American context, the recovery and reappraisal of the term middlebrow has led to a renewed critical interest in the once successful, but subsequently marginalised middlebrow writers. It is to be hoped that the introduction of this critical category in the Italian context would allow us to carefully study the impact of the hitherto marginalized or forgotten work of Pitigrilli and many other writers of the period. Their work, which used to captivate so many readers, certainly deserves greater critical attention than it has hitherto received. 


\section{BIBLIOGRAPHY}

Ardis, Ann L. Modernism and Cultural Conflict, 1880-1922. Cambridge: Cambridge University Press, 2002.

Arnaud, Noël, Lacassin, Francis and Tortel, Jean (eds.). Entretiens sur la paralittérature. Paris: Plon, 1970.

Beauman, Nicola. A Very Great Profession: The Woman's Novel 1914-39. London: Virago, 1983.

Bluemel, Kirsten, ed. Intermodernism: Literary Culture in Mid-Twentieth-Century Britain. Edinburgh:

Edinburgh University Press, 2009.

Bordoni, Carlo. Il romanzo di consumo. Editoria e letteratura di massa. Napoli: Liguori, 1993.

Bordoni, Carlo and Fossati Franco. Dal feuilleton al fumetto - Generi e scrittori della letteratura popolare

. Roma: Editori Riuniti, 1985.

Boshon, Lisa and Meredith Goldsmith (eds.). Middlebrow Moderns: Popular American Women Writers of the 1920s. Boston: Northeastern University Press, 2003.

Brown, Erica and Mary Grover, eds. Middlebrow Literary Cultures: The Battle of the Brows, 1920-1960. London: Palgrave, 2011.

Brown, Erica. Comedy and the Feminine Middlebrow Novel. Elizabeth Van Arnim and Elizabeth Taylor. London: Pickering and Chatto, 2012.

D'hoker, Elke and Nicola Humble. 'Theorizing the Middlebrow: An Interview with Nicola Humble.' Interférences Littéraires. 7 (2001): 295-264. http://www.interferenceslitteraires.be/nl/node/136

Eco, Umberto. Il superuomo di massa. Milano: Bompiani, 1978.

Escarpit, Robert. Sociologie de la littérature. Paris: P.U.F., 1958.

Forgacs, David. L'industrializzazione della cultura italiana (1880-2000). Bologna: Il Mulino, 2000.

Gramsci, Antonio. Letteratura e vita nazionale, Torino, Einaudi, 1950.

Greimas, Algirdas Julien. 'Figurative semiotics and the semiotics of the plastic arts.' New Literary History.20.3 (1989 [1984]): 627-649.

Grover, Mary. The Authenticity of the Middlebrow: Warwick Deeping and Cultural Legitimacy, 1903-1940. Sheffield: Sheffield Hallam University Press, 2002.

Guillory, John. 'The Ordeal of Middlebrow Culture', Review of The Western Canon by Harold Bloom. Transition, 67 (1995): 82-92.

Habermann, Ina. Myth, Memory and the Middlebrow: Priestley, du Maurier and the Symbolic Form of Englishness. Basingstoke: Palgrave Macmillan, 2010.

Hapgood, Lynn and Nancy Paxton. Outside Modernism: In Pursuit of the English Novel, 1900-30. London: Routledge, 2000.

Humble, Nicola. 'Sitting Forward or Sitting Back: Highbrow vs. Middlebrow Reading.' Modernist Cultures. 6.1 (2011): 41-59. 
Humble, Nicola. The Feminine Middlebrow, 1920s to 1950s: Class, Domesticity, and Bohemianism. Oxford: Oxford University Press, 2001.

Hutner, Gordon. What America Read: Taste, Class, and the Novel, 1920-1960. Chapel Hill: University of North Carolina Press, 2009.

Light, Alison. Forever England: Femininity, Literature, and Conservatism Between the Wars. London: Routledge, 1991.

MacDonald, Kate, ed. The Masculine Middlebrow, 1880-1950: What Mr. Miniver Read. London: Palgrave, 2011.

Magri, Enrico. Un italiano vero: Pitigrilli. Milano: Baldini e Castoldi Dalai, 1999.

Maslen, Elizabeth. 'A Cassandra With Clout: Storm Jameson, Little Englander and Good European.' Intermodernism: Literary Culture in Mid-Twentieth-Century Britain. Ed. Kirsten Bluemel. Edinburgh: Edinburgh University Press, 2009.

Pitigrilli. L'esperimento di Pott. Milano: Sonzogno, 1929.

Radway, Janice. A Feeling for Books: The Book-Of-The-Month Club, Literary Taste, and Middle-Class Desire . Chapel Hill: University of North Carolina Press, 1999.

Rak, Michele. La paraletteratura. Il melodramma, il romanzo popolare, il romanzo poliziesco, il fumetto. Napoli: Liguori, 1970.

Rubin, Joan. The Making of Middlebrow Culture. Chapel Hill: University of North Carolina Press, 1992.

Sullivan, Melissa and Sophie Blanch, eds. The Middlebrow - within and without Modernism. Modernist Cultures 6.1, 2011.

Van Boven, Erica and Matthijs Sanders, 'Dutch Middlebrow Literature 1930-1940: Production, Distribution, Reception'. Online. http://europeanmiddlebrow.wordpress.com/

Woolf, Virginia. The Death of the Moth and Other Essays. London: Hogarth Press, 1942.

\section{NOTES}

1. See the contributions to the European Middlebrow Cultures conference, organized in Brussels in January 2014: http://europeanmiddlebrow.wordpress.com/ and the 2012 special issue of Spiegel der Letteren, edited by Erica van Boven et.al.

2. Elisabeth Maslen notes 'My main objection to the term 'middlebrow' is that it brings with it an agenda from the past; it is backward looking. Although many people associate the 'middlebrow' with the protests of Virginia Woolf and Q D Leavis and the debate in the popular press that they helped inspire, it drags into the twentieth century phrenological debates of the nineteenth century, where high, middle and low physical brows were taken as measurable evidence of intelligence and intellectual capacity, and were linked with other debates' (21).

3. Samson is the Italianised name of Charles-Henri Sanson, the Royal Executioner of France during the reign of King Louis XVI and, subsequently, High Executioner of the First French Republic. By referring to Sanson, the novel likens the proceedings at the tribunal to those of the executions in $18^{\text {th }}$-century France. 


\section{ABSTRACTS}

The aim of this essay is to determine whether the concept of the middlebrow can also be translated to cultural and historical contexts other than the Anglo-American one in which it first originated. More particularly, we seek to investigate whether the term can usefully be applied to the Italian literary scene of the first part of the twentieth century. After a short introduction of the different historical and critical uses of the term in Britain and the U.S., we turn to Italy of the early twentieth century for a description of the numerous new developments in writing, publishing and marketing literature. Subsequently, we assess the different ways in which these changes have been analysed and conceptualised in Italian literary criticism, so as to point out the lacunae in this scholarship precisely with regard to writing that falls in between the categories of popular and high literature. By means of one more detailed case study, i.e. the work of the once popular and now forgotten writer Pitigrilli, we argue that his novels share many of the characteristics of the literature labelled as middlebrow in an Anglo-American context. The introduction of this term in Italian criticism, we argue, would undoubtedly lead to a more accurate assessment of his work - and that of other writers like him - within Italian literary history.

\section{INDEX}

Mots-clés: middlebrow literature, Italian literature, interwar period, popular novel, Pitigrilli

\section{AUTHORS}

\section{ELKE D'HOKER}

Elke D'hoker is senior lecturer of English literature at the University of Leuven, where she is also co-director of the Leuven Centre for Irish Studies and of the modern literature research group, MDRN. She has published widely in the field of modern and contemporary British and Irish fiction, with special emphasis on the short story, middlebrow fiction, women's writing and narrative theory. She is the author of a critical study on John Banville (Rodopi, 2004) and has edited or co-edited several essay collections: Unreliable Narration (De Gruyter, 2008), Irish Women Writers (Lang, 2011), Mary Lavin (Irish Academic Press, 2013) and The Irish Short Story (Lang, 2015). Her most recent monograph, Irish Women Writers and the Modern Short Story was published with Palgrave in 2016.

\section{SARAH BONCIARELLI}

Sarah Bonciarelli is postdoctoral fellow and teaching assistant at Ghent University. Her main interests are Italian literature, semiotics and book history. Among her publications are Le avanguardie storiche e la collaborazione interartistica (Franco Cesati, 2014), Littérature et document autour de 1930. Hétérogénéité et hybridation générique, La Licorne, vol. 113 (Presse Universitaire de Rennes, 2014), 'Paratextual Elements and Typographic Techniques: The Evolution of Visual 
Culture in Italian Middle-brow Literature', in The Spaces of the Book (Peter Lang, 2016), 'Bisogna fare della pubblicità come si fa un'opera d'arte. Gabriele D'Annunzio e i percorsi della scrittura letteraria in pubblicità', in Interférences littéraires 18 (2016). 